\title{
Moral and ethical decision-making: A chance for doping prevention in sports?
}

\author{
Marcus Melzer, Anne-Marie Elbe and Ralf Brand
}

Because doping is becoming more and more of a problem in elite sports, antidoping and prevention programs are receiving more attention. However, current doping prevention programs that primarily involve pedagogical education in youths have not been shown to be very effective. In sports philosophy there is a discourse about ethics and morality in sports in connection with doping. So far, however, the aspect of ethics has been neglected in anti-doping prevention programs. This article discusses a new approach to doping prevention for young athletes and a way to improve conventional doping prevention by focusing on the process of decision-making. The article argues that ethical decision-making programs based on ethical training programs developed in business offer a large potential for prevention programs in sport. The article concludes with a presentation of training possibilities for ethical decision-making in connection with doping.

Keywords: doping prevention, ethical decision-making, moral judgment, effectiveness, young athletes

\section{Introduction}

Doping incidents have become an integral part of modern sports; the initial outcries about doping have subsided. It is currently even being discussed whether modern sports can exist without doping (for a review see Møller 2010). This article assumes that athletes in general are against doping and that a control system is necessary for a functioning sport (Backhouse et al. 2007). But the increasing frequency of doping incidents has led to increasing support for the legalization of doping substances (e.g. Savulescu et al. 2004). Furthermore, the doping problem is not limited just to modern elite 
sports, which makes it impossible to solve it solely within the sports context (e.g., Bette 2001).

Most people in Western societies believe that participation in sport has pedagogical values (cf. Arnold 1994; Arvaniti 2006). However, this belief conflicts with the goal of winning at all costs, which is also an integral part of modern high-performance sports (see Volkwein 1995). Because doping also occurs in recreational sports (Müller-Platz et al. 2006), the so-called spirit of sport is threatened when athletes dope (see WADA 2009). The World Anti-Doping Agency (WADA) defines the spirit of sport as «the celebration of the human spirit, body and mind which is characterized by the following values: ethics, fair play and honesty, health, excellence in performance, character and education, fun and joy, teamwork, dedication and commitment, respect for rules and laws, respect for self and other participants, courage as well as community and solidarity» (WADA 2009: 14).

The spirit of sport embodies an ideal-perhaps a moral principle (Foot \& Harrison 1954) — which especially young athletes should be encouraged to seek. But this pursuit of a moral standard involves more people than just the athletes themselves. Contextual factors such as the pressure to win create a «sticky situation of sportsmanship» (May 2001: 372), so that winning alone is the highest value for young athletes. All other personal values are subordinated to the central goal of winning (see Pilz 1995; Kavussanu \& Roberts 2001). Consequently, because the main target group of doping prevention should be youth sports rather than professional sports, it is important to take a new path in doping prevention in line with the spirit of sport. Such fundamental ethical values of sport are also important for young athletes today (Pilz 1995). We propose that the development of pedagogical programs for young athletes should stress the values associated with the spirit of sport. Our effort should lie in the Coubertin ideal: "The important thing in life is not victory, but struggle: the essential is not to conquer, but to fight well» (Coubertin 2000: 587).

\section{How to define doping?}

Usually, doping is defined solely in relation to drug abuse. In 1963 the European Parliament's legal definition of doping was the «abnormal intake of exogenous substances in healthy people with the primary intention to artificially enhance performance» (see Reiter 1994: 191). This definition, however, did not clearly establish which substances, substance classes, or methods were included. Hence, in 1968 the International Olympic Committee (IOC) tried to specify the term doping by means of a negative list of prohibited substances and methods (see Mottram 1999). However, these kinds of definitions are useless for prevention purposes (Binsinger \& Friser 
2002), because they do not mention or describe the underlying behavior (for an overview of critiques see Bird \& Wagner 1997).

The WADA's most recent definition of doping incorporates both a negative list of banned substances and a description of various behaviors related to them. The WADA formulated eight anti-doping rules (WADA 2009). These rules describe, within bounds, how violations are penalized. The detection of a forbidden substance or method constitutes a direct violation of the doping rules, and the attempt to take, the possession of, and the circulation of doping substances are all regarded as offenses. Moreover, the WADA counts it an offense when a doping control is refused or dates for a control are not met. The manipulation of doping controls presents an offense against the anti-doping rules, as does any attempt to give an athlete forbidden substances or to try out forbidden methods on him or her (i.e., third-party involvement). The WADA annually specifies which substances and methods are forbidden in the respective year. Doping represents the abuse of performance enhancing substances and methods and includes all related actions. This recent doping definition is more comprehensive than all previous ones. Additionally, this definition includes the possible involvement of third parties, who could also be responsible for doping. But Møller (2010: 7) points out that the «root of the difficulties that the anti-doping campaign has to wrestle with remains precisely because the concept of doping has not been sufficiently clarified.» We agree with Møller (2010) that the act of doping has not yet been adequately defined. For prevention purposes it seems less promising when the behavior is linked only to certain substances and methods. So perhaps we must broaden our view to the individual's thinking about doping and doping behavior. In our view, in order to early recognize and prevent endangerment, psychological aspects, such as doping-related cognitions and decision-making (i.e., behavior regulation) need to be focused on.

\section{«Conduite dopante», doping mentality: A definition}

Laure (e.g., 1997; 2000) translates doping using the term conduite dopante (doping behavior), a specific behavior that is shown in many aspects of life. This doping behavior encompasses all actions in connection with the consumption of performance enhancing substances (Laure 1997). More precisely, conduite dopante refers to an individual's disposition that perhaps is better described as a doping mentality (Arndt et al. 2004). This comprehensive construct demands a theoretical description that is more encompassing than mere intention or a pattern of behavior.

Various studies of addiction have shown that value-orientations have an effect on drug use (cf. Brook \& Whitehead 1983; Castro et al. 2009). We sug- 
gest including the idea of a materialistic value orientation in the term doping mentality. The existing definition of doping is based on behaviors in connection with the legal or illegal use of drugs to enhance or keep up performance (Laure 2002; Favre \& Laure 2002). This, however, neglects the fact that attitudes or intentions for a certain behavior can exist but do not necessarily immediately manifest themselves in actual behavior (e.g., Sheeran 2002). The simultaneous existence of individual dispositions (Sniehotta, Scholz \& Schwarzer 2005) and situational opportunities (Ajzen 1985) increases the probability that the behavior occurs. But it is a fact that individual predispositions for such a behavior already exist. Therefore, it is partial to define doping solely as an exhibited behavior. The underlying values and processes leading to this behavior must be taken into consideration as well.

If, however, one assumes that how a person pursues their goals is part of their individual developmental process, then one must understand doping as a doping mentality. Such a doping mentality is a stable and complex personality characteristic that influences behavior formation by means of different mechanisms. Personality is determined by individual learning experience and socialization as well as by different attitudes, values, goals, and features of information processing. Hence, one's personality influences whether or not achievement situations addressing personal goals involve an increased likelihood of substance abuse. Bette and Schimank (2006) talk in terms of coping with doping. Here, doping is seen as a subjective rational choice, based on individual decisions and specific contextual factors, which are constrained by inner and outer demands.

The contradiction that although the majority of the athletes condemn doping (Backhouse et al. 2007) but at the same time accept this behavior under certain circumstances, clearly shows the inner conflict that athletes experience. Therefore, the individual perspective of this decision-making process on whether to dope or not should receive more attention. In the following, we will argue that the decision-making process especially in relation to ethics is missing in the current debate on doping and doping prevention. We believe that integrating ethical awareness into the decision-making process can prevent doping and we therefore discuss ethical behavior in sport.

\section{Ethical behavior in sport}

The term ethics originates from the two Greek words éthos, meaning «character» or «custom» (Solomon 1984), and êthos, which translates into «wellestablished or institutionalized practice» (Loland 2002: 17). In our opinion, ethics relates to societal values of right and wrong (Singer 1986). An ethical judgment is coherent with philosophical standards for ideal human behavior (e.g., Kant's Categorical Imperative, Gandz \& Hayes 1988). 
In sports the ethics discourse belongs to the discipline of sports philosophy. Sport ethics sees its most urgent task in presenting problem-focused solutions for the doping discussion (Pawlenka 2004). However, a meaningful discussion of ethics in sports can only take place by carefully analyzing the term sport (Steenbergen \& Tamboer 1998). The realm of sport is closely tied to ethical questions, which is due to the fact that human behavior is characterized by interaction with other individuals (McFee 1998). Moreover, the bond results from sport itself, because several ethical values are ascribed to it. Because it is rule-based (e.g., Alderson \& Crutchley 1990) sport is often seen as the embodiment of ethical behavior (McFee 1998). This even becomes apparent in terms such as sportsmanship, fair play, and playing by the rules. McFee (1998: 5) points out that «ethical issues arise... from the nature of sport.»

Considering this meaning of sport, it is not surprising that the occurrence of unethical behavior weighs even more heavily, because it attacks sport's innermost values. This idealistic ascribing of moral meaning to sport is called Sportethos (Kuchler 1969), which stresses the educational possibilities that sport activities can entail.

The close connection between sport participation and moral development, however, only has weak empirical support (Kavussanu \& Ntoumanis 2003). It therefore seems more appropriate to look for the mediating factors contributing to moral development in sport. Sport in general does not turn individuals into moral people. In contrast, unethical behavior seems to be more accepted in sports than in daily life (Bredemeier \& Shields 1984).

Franke (1978) describes sport as «a world in itself» due to two opposing principles: on the one hand, athletes have to defeat their opponents, while on the other hand they should show utmost fairness. Franke (1988) states this as a «system of immanent tension» (cited in Steenbergen \& Tamboer 1998: 36).

Consequently, sport can contribute to the moral development of children and young adults only to a certain degree. In general, ethical and moral behavior can only be learned in the whole societal context. Sport represents only one context in which to teach ethical values and principles, but it facilitates their acceptance.

\section{Doping: An ethical problem?}

Finally, the question arises as to what degree a balance between these opposing principles exists in modern sport. Volkwein (1995) sees the development of modern elite sport as the pinnacle of society's performance demands. The reasons for this development lie in the socio-cultural context, which is limited by three conditions: (1) winning at all costs, (2) the over- 
emphasis on success, and (3) the body as an element of uncertainty (Volkwein 1995: 311). Underlying these conditions are financial and material considerations, which are increasingly dominating elite sport (cf. Göral, Caliskan \& Yetim 2009).

The significance of sport and its ethical implications are emphasized especially in children's and youth sports literature (cf. Shields \& Bredemeier 1995). McNamee (2009: 115) points out that even though young athletes' self-determination grows during adolescence, they are still «vulnerable to certain controlling influences that may undermine their rational and autonomous decision making.» Thus, it seems natural that young people's individual moral judgment abilities should be strengthened to enable them to understand the consequences of their self-determined decisions. Therefore, preventive measures are predominantly geared towards youth and leisure sports, because they are more accessible than sub-culturally organized elite sports.

Recent research on prevention programs has found that an isolated intensification of sanctions in order to increase the individual costs shows only limited success (Petroczi \& Aidman 2008). The effectiveness of sanction-oriented doping prevention is always determined by various factors (e.g., 2-year doping suspension and additional loss of bonuses). Following the rational choice approach (Cornish \& Clarke 1986), the individual rationally assesses the costs (expected sanctions) and the benefits of a certain behavior in order to reach a balanced decision (e.g., Strelan \& Boeckmann 2003). This cost-benefit consideration plays a central role in the deterrence theory (Paternoster 1987). If the expected sanctions have a high probability of occurring and exceed the benefit of the action, then a deterrent effect can be seen (Paternoster 1987; Strelan \& Boeckmann 2003). Strelan and Boeckmann (2006) emphasize that the deterrence effect should be evaluated in connection with the type of illegal behavior. However, so far, the validity of the deterrence hypothesis has not been satisfactorily proven, especially in relation to the severity of the punishment (Dölling et al. 2009).

In contrast, Rupp (2008) maintains that it is the individual's acceptance of the underlying moral principle represented by the law that determines the effectiveness of a deterrent. An individual must consider the underlying norm to be valuable in order to assign moral importance to it. Nagin and Pogarsky (2003) emphasize that moral inhibition (i.e., insensitivity to moral values) plays an essential role in the decision-making process connected to criminal behavior. Paternoster and Simpson (1996) show that internalization of moral rules can have a decisive effect on criminal intention. Interestingly, this effect remains even under control for the influence of the expected costs and benefits.

In conclusion, sport activities in themselves are neither moral nor ethical. The sport ethos does not guarantee that athletes will show moral beha- 
vior. Rather, it is the duty of all participants involved in sport to protect the immanent idea of fair competition. Because sport is a world of its own (Franke 1978), it is necessary that different standards are set for sport than for the rest of society (cf. Bredemeier \& Shields 1984).

Especially because moral responsibility and implications are ascribed to sport, moral norms and attitudes should be considered in sport education. The idea of limitless achievement poses many ethical and moral questions. Long et al. (2006) show that athletes view rule transgression as a legitimate tactical method. As a possible explanation for this behavior, athletes state the desire to win and consider these forms of «modest» rule violation as part of the game (see Pilz 1995).

The social environment, especially coaches and teammates have a great influence on the likelihood of unsportsmanlike behavior occurring (Long et al. 2006). Also peer groups and the connected moral beliefs in groups have a strong influence on doping (Papadopoulos, Skalkidis, Parkkari, Petrodou \& «Sports Injuries» European Union Group 2006). In scientific terms, this is described as the moral atmosphere (cf. Jones \& McNamee 2000).

Current research shows that low moral abilities are closely connected to unethical behavior also in sport (cf. Bredemeier \& Shields 1994). Hence, the question arises why, so far, have prevention programs usually neglected these aspects of moral ability and unethical behavior?

\section{Moral education and ethical training as a chance for doping prevention}

Most prevention programs are health education based and focus on conveying necessary knowledge in order to change doping attitudes and/or decrease the intention to dope (e.g., Goldberg et al. 2000; Laure \& Lecerf 2002). However, there is only weak empirical evidence for the effectiveness of such knowledge-based prevention programs (Laure \& Lecerf 1999; 2002). Hanson (2009) points out that it is insufficient to merely focus on teaching knowledge about doping. Further educational approaches need to be included. We believe that interventions designed to question the validity of athletes' existing beliefs (see Hanson 2009: 395) and that stimulate a critical reflection about doping are more promising. The traditional way of education produces knowledge that is difficult to apply when the actual situation arises.

Hanson (2009) describes different aspects of how to improve the current anti-doping education. First, the programs need to be evaluated on a regular basis. A lot of prevention is conducted without any documentation of effects, results, or theoretical background. The results are wasted resources 
and limited theoretical conclusions. Secondly, doping prevention should be orientated on already existing knowledge levels. Here, further research is required and has to assess how this knowledge changes throughout an athlete's career.

A methodological difficulty in doping research is the measurement of changes in doping behavior, especially stable changes, using reliable and valid instruments of substance abuse. The most commonly used dependent variables are knowledge about doping (e.g., Goldberg et al. 1990; Goldberg et al. 2000; Goldberg \& Elliot 2005), the attitude towards doping (e.g., Laure \& Lecerf 1999), and the subjectively assessed intention to dope (e.g., Goldberg \& Elliot 2005). Backhouse et al. (2007) comprehensively show that these factors have only little explanatory power in relation to actual doping behavior. In addition to methodological difficulties, studies usually have theoretical weaknesses (e.g., different definitions of doping attitude).

The most commonly applied model used to explain doping behavior is the theory of planned behavior by Ajzen (1985) (see Backhouse et al. 2007). In contrast to this common opinion, we postulate that doping is not solely a planned action. The decision to dope is also characterized by spontaneous and weakly evaluated cognitive processes (cf. Petroczi et al. 2008). We follow the prevalent approach in cognitive science that the act of decisionmaking contains dual modes of processing (see Chaiken \& Trope 1999). Because health education based programs only show weak, if any, effects, we feel that cognitive structures need to be changed to incorporate interpersonal control processes, such as ethical decision-making.

\section{Moral judgment abilities - a crucial point of ethical decision-making}

Moral judgment has shown to be an effective component of the ethical decision-making process (cf. Kohlberg 1964; Colby et al. 1983). Kohlberg (1964: 425) describes an individual's moral judgment competence as «the capacity to make decisions and judgments that are moral (i.e., based on internal principles) and to act in accordance with such judgments.»

The consideration of the process of ethical decision-making is more than the evaluation of the behavior in terms of right and wrong. Usually, the result of such an evaluation process contains individually weighted decisions, which are consistent with the own actual activated values, ideals, or goals. Especially the personally emphasized pressure to reach self- or otherdetermined goals could increase the likelihood of unethical behavior (Schweitzer et al. 2004). 


\section{Ethical decision-making in business organizations}

Research on ethical decision-making in business has a long tradition. Different literature reviews (see Loe et al. 2000, O’Fallon \& Butterfield 2005) about ethical decision-making in business show that it is determined by a variety of individual and organizational factors, such as gender, ethical awareness, organizational culture, codes of ethics, rewards and sanctions, and ethical climate. Brinkmann and Sims (2001) formulated seven primary goals of business ethics courses: (1) knowledge about own moral values, (2) moral awareness, (3) training moral judgment, (4) sharing moral understanding, (5) handling moral conflicts, (6) moral courage, and (7) critical attitude towards business ethics and questioning the content of ethic courses. A number of findings document the effectiveness of ethical training in business (cf. Delaney \& Sockell 1992; Gautschi \& Jones 1998; Weber \& Glyptis 2000). But again, it needs to be differentiated whether ethics are merely taught (Burton et al. 1991) or whether the ethical decision-making process is the direct focus of the intervention (e.g., Kavathatzopoulos 1994; 2002). Kavathatzopoulos (1993) and Levin (1989) both note the effectiveness of training the underlying cognitive abilities to solve moral problems.

We see an advantage in applying findings from the field of decisionmaking in business ethics to sports. Sport is known for being a «big business» (Robinson 2003: 165), and many teams can be compared to large business enterprises. For many athletes, sport is their vocation, their way of earning a living. Maximizing profits has become a goal in sports and athletes are under a lot of pressure to succeed, just like employees in businesses. Ethical considerations are often neglected because they are seen as a barrier to success.

\section{Moral and ethical decision-making training in sport}

Ethical considerations about the use of performance-enhancing substances in sport are widely discussed (see Volkwein 1995; Bockrath \& Franke 1995; Hemphill 2009). Nevertheless, literature about the relevance of ethical behavior in doping prevention is rare. Only the Scandinavian countries have shown a long-time tradition of integrating ethics into their antidoping campaigns (Gilberg et al. 2006). Denmark, for example, offers an educational online tool (DopingAkademiet ${ }^{1}$ ) for coaches, which enables them to remain informed about doping facts and problems. Norway also has a long tradition of focusing on ethical behavior in sport (Gilberg et al. 2006). Unfortunately, however, there are no internationally published studies that have documented the effectiveness of these programs. Moreover, the Scandinavian anti-doping campaigns are generally based on tradi- 
tional teaching, which is less effective for understanding concepts (see Hanson 2009).

Our study aims at establishing and evaluating the effectiveness of an anti-doping training focusing on the detailed ethical decision-making process. We assume that the process of cognitive appraisal and the evaluation of supporting and opposing arguments require strong mental skills and capacities that may not be intuitively available. Moral abilities require a process of intensive learning and training (cf. Wright 1995; Lind 2009), which is enforced by the constant confrontation with everyday ethical problems.

Blatt (1969) focuses on this dialog of for and against. He utilizes dilemma discussions in order to analyze moral problems (cf. Blatt \& Kohlberg 1975). Lind (cf. Lind 2009) has continued with this approach in the dilemma discussion and developed a comprehensive method for training moral abilities. The effectiveness of dilemma discussions has been sufficiently shown (e.g., Lerkiatbundit et al. 2006). The first studies in relation to drug consumption and doping highlight moral abilities as a protective factor (cf. Donovan et al. 2002; Amonini \& Donovan 2006; Long et al. 2006).

We therefore find it necessary to include the component of ethical decision-making in the anti-doping prevention. In our opinion, athletes have a clear understanding of permitted and forbidden behavior in a sports context, even if they are not always wholly knowledgeable about the prohibited substances and methods. Many studies, especially those concerning doping, show that the majority of athletes condemn doping (see Laure 1997). The stability of such attitudes, however, is strongly determined by the current context making an individual's decision inconsistent (for a review see Backhouse et al. 2007). Doping should not be conceptualized as a long-planned decision but one strongly influenced by different personal and situational factors. We argue that it is necessary to take a look at an important influential factor, the ethical and moral decision-making ability, and to show how it can be strengthened.

Accordingly, we are currently developing a web-based decision-making training program in which the participants have to tackle different sportspecific dilemma situations. These are based on the method of dilemma discussion by Lind (2009), but expanded by the component of having to actually make a decision. Dealing with supporting and contradicting arguments is a key part of the moral decision process. Therefore, the training focuses on dealing with different arguments.

The participants are confronted with different ethical dilemma situations, which they have to resolve spontaneously. Afterwards they are asked how satisfied they are with their decision. Thereafter, the actual training process starts. Following Barry's (1979) analytical framework for ethical decision-making, participants are confronted with pro and con arguments that are based on a cost-benefit analysis, on rules or norms that are cultur- 
ally determined, and arguments that are characterized by focusing on specific ethical principles (e.g., the Categorical Imperative) (for a review see Gandz \& Hayes 1988). Culturally determined arguments are based on ethical relativism, which means that certain moral standards are local, transient, and variable (Gandz \& Hayes 1988). Based on these arguments, which are to support or question the decision, reflective moral evaluation of the initially made decision is evoked. Consistently, the consideration of counterarguments when making decisions demonstrates a high moral quality (cf. Lind 2000).

The goal of a current WADA funded project entitled «Being a fair sportsman: Ethical decision making as a chance for doping prevention?» is to test this intervention in a randomized study, with young elite athletes in Germany. The objective is to design ethical dilemmas based on different ethical climates of sport contexts and to compare three experimental groups (1: ethical decision-making training; 2: psycho-educational training; 3 : combined training of both trainings) with a waiting-control group with respect to the program's effectiveness and the athletes' ability to solve sports-specific ethical dilemmas.

\section{Conclusion}

The research on the effectiveness of doping prevention programs points out the importance of alternative methods. The aim of the research perspective described in this paper is to document that training of ethical decisionmaking in young elite athletes may have stronger effects on altering behavior than mere education-based prevention programs. We are aware that ethical decision-making training is only one factor that can influence the decision of whether to dope. Another strong influencing factor seems to be athletes' environment and the exerted pressure by coaches and teammates. Therefore, it might be useful to include all stakeholders in such ethical training in order to change environmental factors as well.

\section{Acknowledgements}

We would like to thank Verner Møller and two anonymous reviewers for their valuable comments on an earlier version of this manuscript. This project is being carried out with the support of WADA. 


\section{Notes}

1 For detailed information http://www.antidoping.dk/Raadgivning/Onlinekursus_for _traenere.aspx

\section{Literature}

Ajzen, I. (1985) From intentions to actions: A theory of planned behavior. I Actioncontrol: From cognition to behavior, eds. J. Kuhl \& J. Beckmann, pp. 17-33. Heidelberg: Springer.

Alderson, J. \& Crutchley, D. (1990) Physical education \& the national curriculum. I New Directions in Physical Education, ed. N. Armstrong, pp. 37-62. Champaign, IL: Human Kinetics.

Amonini, C. \& Donovan, R.J. (2006) The relationship between youth's moral and legal perceptions of alcohol, tobacco and marijuana and use of these substances. Health Education Research, 21 (2), pp. 276-286.

Arndt, N., Singler, A. \& Treulein, G. (2004) Sport ohne Doping. Argumente und Entscheidungshilfen für junge Sportlerinnen und Sportler sowie Verantwortliche in deren Umfeld [Sport without doping. Argumentation and help for decision making for young athletes and their surroundings]. Frankfurt/Main: Deutsche Sportjugend.

Arnold, P.J. (1994) Sport and moral education. Journal of Moral Education, 23 (1), pp. $75-89$.

Arvaniti, N. (2006) Ethics in sport: The Greek educational perspective on antidoping. Sport in Society, 9 (2), pp. 354-370.

Backhouse, S., McKenna, J., Robinson, S. \& Atkin, A. (2007) Attitudes, behaviours, knowledge and education - drugs in sport: past, present and future. Downloaded 10 October 2009 from http://www.wada-ama.org/en/Education-Awareness/ Social-Science/Funded-Projects/

Barry, V. (1979) Moral issues in business. Belmont, CA: Wadsworth.

Bette, K.H. (2001) Kollektive Personalisierung. Strukturelle Defizite im Dopingdiskurs [Collective personalization. Structural deficits in doping dicussion]. I Spitzensport: Chancen und Probleme, ed. H. Digel, pp. 26-42. Schorndorf: Hofmann.

Bette, K.H. \& Schimank, U. (2006) Die Dopingfalle: Soziologische Betrachtungen [The doping trap: Sociologist considered]. Bielefeld, transcript.

Binsinger, C. \& Friser, A. (2002) Du dopage en particulier aux conduites dopantes en général: le point sur les connaissances [Doping in particular and doping behavior in general: Summary about knowledge]. Psychotropes, 8 (3-4), pp. 922.

Bird, E. \& Wagner, G. (1997) Sport as a common property resource: A solution to the dilemmas of doping. Journal of Conflict Resolution, 41 (6), pp. 749-766.

Blatt, M.M. \& Kohlberg, L. (1975) The effects of class-room moral discussion upon children's level of moral judgment. Journal of Moral Education, 4 (2), pp. 129161.

Blatt, M.M. (1969) The effects of classroom discussion upon children's level of moral reasoning. Unpublished doctoral dissertation, University of Chicago. 
Bockrath, F. \& Franke, E. (1995) Is there any value in sports? About the ethical significance of sport activities. International Review for the Sociology of Sport, 30 (3-4), pp. 283-310.

Bredemeier, B.J. \& Shields, D.L. (1984) Divergence in moral reasoning about sport and life. Sociology of Sport Journal, 1, pp. 348-357.

Bredemeier, B.J. \& Shields, D.L. (1994) Applied ethics and moral reasoning in sport. I Moral Development in the Professions, eds. J.R. Rest \& D. Narvaez, pp. 173-188. Hillsdale, NJ: Lawrence Erlbaum.

Brinkman J. \& Sims, R.R. (2001) Stakeholder-sensitive business ethics teaching. Teaching Business Ethics, 5 (2), pp. 171-193.

Brook, R.C. \& Whitehead, P.C. (1983) Values of adolescent drug abusers. International Journal of the Addictions, 18 (1), pp. 1-7.

Burton, S., Johnston, M. \& Wilson, E. (1991) An experimental assessment of alternative teaching approaches for introducing business ethics to undergraduate students. Journal of Business Ethics, 10 (7), pp. 505-517.

Castro, F.G., Stein, J.A. \& Bentler, P.M. (2009) Ethnic pride, traditional family values, and acculturation in early cigarette and alcohol use among latino adolescents. The Journal of Primary Prevention, 30 (3-4), pp. 265-292.

Chaiken, S. \& Trope, Y. (1999) Dual process theories in social psychology. New York, Guilford Press.

Colby, A., Kohlberg, L., Gibbs, J.C., Lieberman, M., Fischer, K. \& Saltzstein, H.D. (1983) A longitudinal study of moral judgment. Monographs of the Society for Research in Child Development, 48 (1-2), pp. 1-124.

Cornish, D.B. \& Clarke R.V. (1986) The reasoning criminal: Rational choice perspectives on offending. New York: Springer.

Coubertin, P. de (2000) Olympism: Selected writings. Pierre de Coubertin 18631937. Lausanne: IOC.

Delaney, J. T. \& Sockell, D. (1992) Do company ethics training programs make a difference? An empirical analysis. Journal of Business Ethics, 11 (9), pp. 719727.

Dölling, D., Entorf, H., Hermann, D. \& Rupp, T. (2009) Is deterrence effective? Results of a meta-analysis of punishment. European Journal on Criminal Policy and Research, 15, pp. 201-224.

Donovan, R.J., Egger, G., Kapernick, V. \& Mendoza, J. (2002) A conceptual framework for achieving performance enhancing drug compliance in sport. Sports Medicine, 32 (1), pp. 269-284.

Favre, A. \& Laure P. (2002) Conduites dopantes: à quoi s'engage-t-on? [Doping behavior: what do you engage for?]. Psychotropes, 8 (3-4), pp. 23-29.

Foot, P.R. \& Harrison, J. (1954) When is a principle a moral principle? Proceedings of the Aristotelian Society, Supplementary Volumes, 28, pp. 95-134.

Franke, E. (1978) Theorie und Bedeutung sportlicher Handlungen. Voraussetzungen und Möglichkeiten einer Sporttheorie aus handlungstheoretischer Sicht [Theory and meaning of sport actions]. Schorndorf: Hofmann.

Franke, E. (1988) Ethische Aspekte des Leistungssports [Ethical aspects of highperformance sport]. Clausthal-Zellerfeld: Deutsche Vereinigung für Sportwissenschaft.

Gandz, J. \& Hayes, N. (1988) Teaching business ethics. Journal of Business Ethics, 7 (9), pp. 657-669. 
Gautschi III, F.H. \& Jones, T.H. (1998) Enhancing the ability of business students to recognize ethical issues: An empirical assessment of the effectiveness of a course in business ethics. Journal of Business Ethics, 17 (2), pp. 205-216.

Gilberg, R., Breivik, G. \& Loland, S. (2006) Anti-doping in Sport: The Norwegian perspective. Sport in Society, 9 (2), pp. 334-353.

Goldberg, L. \& Elliot, D.L. (2005) Preventing substance use among high school athletes: The ATLAS and ATHENA programs. Journal of Applied School Psychology, 21 (2), pp. 63-87.

Goldberg, L., Bosworth, E.E., Bents, R.T. \& Trevisan, L. (1990) Effect of an anabolic steroid education program on knowledge and attitudes of high school football players. Journal of Adolescent Health Care, 11 (3), pp. 210-214.

Goldberg, L., MacKinnon, D.P., Elliot, D., Moe, E., Clarke, G. \& Cheong, J. (2000) The adolescents training and learning to avoid steroids program: Preventing drug use and promoting health behaviors. Archives of Pediatric and Adolescent Medicine, 154 (4), pp. 332-338.

Göral, M., Caliskan, G. \& Yetim, A. (2009) Relationship of sports and morality and sports morality of individuals interested in sports. The Social Science, 4 (3), pp. 269-277.

Hanson, J. M. (2009) Equipping athletes to make informed decisions about performance-enhancing drug use: A constructivist perspective from educational psychology. Sport in Society, 12 (3), pp. 394-410.

Hemphill, D. (2009) Performance enhancement and drug control in sport: Ethical considerations. Sport in Society, 12 (3), pp. 313-326.

Jones, C. \& McNamee, M.J. (2000) Moral reasoning, moral action and the moral atmosphere of sport: Some critical remarks on the limitations of the prevailing paradigm. Sport, Education and Society, 5 (3), pp. 131-148.

Kavathatzopoulos, I. (1993) Development of a cognitive skill in solving business ethics problems: The Effect of Instruction. Journal of Business Ethics, 12 (5), pp. 379-386.

Kavathatzopoulos, I. (1994) Training professional managers in decision-making about real life business ethics problems: The acquisition of the autonomous problem-solving skill. Journal of Business Ethics, 13 (5), pp. 379-386.

Kavathatzopoulos, I. (2002) Ethical competence training for individuals and organizations. I Moral leadership in action, ed. H. von Weltzien Høivik, pp. 293-303. Cheltenham, UK: Edward Elgar Publishing.

Kavussanu, M. \& Ntoumanis, N. (2003) Participation in sport and moral functioning: Does ego orientation mediate their relationship? Journal of Sport \& Exercise Psycholog, 25 (4), pp. 1-18.

Kavussanu, M. \& Roberts, G.C. (2001) Moral functioning in sport: An achievement goal perspective. Journal of Sport \& Exercise Psychology, 23 (1), pp. 37-54.

Kohlberg, L. (1964) Development of moral character and moral ideology. I Review of child development research, eds. M.L. Hoffman \& L.W. Hoffman, pp. 381431. New York: Russel Sage Foundation.

Kuchler, W. (1969) Sportethos. Eine moraltheologische Untersuchung des im Lebensbereich Sport lebendigen Ethos als Beitrag zu einer Phänomenologie der Ethosformen [Sportethos. A moral-theological investigation of the Ethos alive in sport as a contribution to a phenomenology of Ethos forms]. München: Barth.

Laure, P. (1997) Médecins généralistes et dopage sportif: connaissances et attitudes [General practitioner and doping in sport]. Santé Publique, 9, pp. 145-156. 
Laure, P. (2000) Doping: Epideminological studies. Presse Medicale, 29 (24), pp. $1365-1372$.

Laure, P. (2002) Les conduites dopantes: une prévention de l'échec? [Doping mentalilty: a prevention of fualure?]. Psychotropes, 8 (3-4), pp. 31-38.

Laure, P. \& Lecerf, T. (1999) Prevention of doping in sport in adolescents: Evaluation of a health educationbased intervention. Archive Pediatrics, 6 (8), pp. 848854.

Laure, P. \& Lecerf, T. (2002) Doping prevention among young athletes: Comparison of a health education-based intervention versus information-based intervention. Science \& Sports, 17 (4), pp. 198-201.

Lerkiatbundit, S., Utaipan, P., Laohawiriyanon, C. \& Teo, A. (2006) Randomized controlled study of the impact of the Konstanz method of dilemma discussion on moral judgment. Journal of Allied Health, 35 (2), pp. 101-108.

Levin, M. (1989, November 25) Ethics course: Useless. New York Times.

Lind, G. (2000) The importance of role-taking opportunities for self-sustaining moral development. Journal of Research in Education, 10 (1), pp. 9-15.

Lind, G. (2009) Moral ist lehrbar. Handbuch zur Theorie und Praxis moralischer und demokratischer Bildung [Morality can be taught. Handbook on theory and practice of moral and democratic education]. München: Oldenbourg.

Loe, T.W., Ferrell, L. \& Mansfield, P. (2000) A review of empirical studies assessing ethical decision making in business. Journal of Business Ethics, 25 (3), pp. 185204.

Loland, S. (2002) Fair Play in Sport: A Moral Norm System. London: Routledge.

Long, T., Pantaléon, N., Bruant, G. \& d'Arripe-Longueville, F. (2006) A qualitative study of moral reasoning of young elite athletes. The Sport Psychologist, 20, pp. 330-347.

May, R.A.B. (2001) The sticky situation of sportsmanship: Contexts and contradictions in sportsmanship among high school boys basketball players. Journal of Sport and Social Issues, 25 (4), pp. 372-389.

McFee, G. (1998) Are there philosophical issues in respect of sport (other than ethical ones)? I Ethics and sport, eds. M.J. McNamee \& S.J. Parry, pp. 3-18. London: Routledge.

McNamee, M.J. (2009) Beyond consent: The ethics of pediatric doping. Journal of the philosophy of sport, 36, pp. 111-126.

Mottram, D.R. (1999) Banned drugs in sport: Does the international olympic committee (IOC) list need updating? Sports Medicine, 27 (1), pp. 1-10.

Møller, V. (2010) The ethics of doping and anti-doping. Redeeming the soul of sport? London: Routledge.

Müller-Platz, C., Boos, C. \& Müller, K. (2006) Doping beim Freizeit- und Breitensport [Doping in recreational and mass sports]. I Gesundheitsberichterstattung des Bundes, Heft 34, ed. Robert-Koch-Institut. Berlin: Robert-Koch-Institut.

Nagin, D.S. \& Pogarsky, G. (2003) An experimental investigation of deterrence: Cheating, self-serving bias and impulsivity. Criminology, 41 (1), pp. 501-527.

O'Fallon, M.J. \& Butterfield, K.D. (2005) A review of the empirical ethical decisionmaking literature. Journal of Business Ethics, 59 (4), pp. 375-413.

Papadopoulos, F.C., Skalkidis, I., Parkkari, J., Petridou, E. \& «Sports Injuries» European Union Group (2006) Doping use among tertiary education students in six developed countries. European Journal of Epidemiology, 21 (4), pp. 307313. 
Paternoster, R. (1987) The deterrence effect of the perceived certainty and severity of punishment: A review of the evidence and issues. Justice Quarterly, 4 (2), pp. 173-217.

Paternoster, R. \& Simpson, S. (1996) Sanction threats and appeals to morality: Testing a rational choice model of corporate crime. Law and Society Review, 30 (3), pp. 549-583.

Pawlenka, C. (2004) Sportethik. Regeln - Fairneß - Doping [Sport ethic. Rules - fairness - doping]. Paderborn: mentis.

Petroczi, A. \& Aidman E. V. (2008) Psychological drivers in doping: the life-cycle model of performance enhancement. Substance Abuse Treatment, Prevention, and Policy. Downloaded 17 October 2009 from http://substanceabusepolicy.com/content/3/1/7

Petroczi, A., Aidman, E.V. \& Nepusz, T. (2008) Capturing doping attitudes by selfreport declarations and implicit assessment: A methodology study. Substance Abuse Treatment, Prevention, and Policy. Downloaded 5 November 2009 from http://www.substanceabusepolicy.com/content/3/1/9

Pilz, G.A. (1995) Performance sport: Education in fair play? International Review for the Sociology of Sport, 30 (3-4), pp. 391-418.

Reiter, H. (1994) Bericht der Unabhängigen Dopingkommission des Deutschen Sportbundes (DSB) und des Nationalen Olympischen Komitees (NOK) [Report of the independent doping comission of the german sports association and of the national olympic committee]. I Doping im Leistungssport - Sozialwissenschaftlich beobachtet, ed. K.H. Bette, pp. 191-231. Stuttgart: Nagelschmid.

Robinson, L. (2003) The business of sport. I Sport and society, ed. B. Houlihan, pp. 165-183. London: Sage.

Rupp, T. (2008) Meta analysis of crime and deterrence: A comprehensive review of the literature. Unpublished doctoral disseratation. Downloaded 13 October 2009 from http://tuprints.ulb.tu-darmstadt.de/1054/2/rupp_diss.pdf

Savulescu, J., Foddy, B. \& Clayton, M. (2004) Why we should allow performance enhancing drugs in sport. British Journal of Sports Medicine, 38, pp. 666-670.

Schweitzer, M.E., Ordóñez, L. \& Douma, B. (2004) Goal setting as a motivator of unethical behavior. Academy of Management Journal, 47 (3), pp. 422-432.

Sheeran, P. (2002) Intention-behavior relations: A conceptual and empirical review. European Review of Social Psychology, 12, pp. 1-36.

Shields, D.L. \& Bredemeier, B.J. (1995) Character Development and Physical Activity. Champaign: Human Kinetics.

Singer, P. (1986) Applied ethics. Oxford: Oxford University Press.

Sniehotta, F.F., Scholz, U. \& Schwarzer, R. (2005) Bridging the intention-behaviour gap: Planning, self-efficacy, and action control in the adoption and maintenance of physical exercise. Psychology and Health, 20 (2), pp. 143-160.

Solomon, R.C. (1984) Ethics. A brief introduction. New York: McGraw-Hill.

Steenbergen, J. \& Tamboer, J.W.I. (1998) Ethics and the double character of sport: An attempt to systematize the discussion on the ethics of sport. I Ethics and sport, eds. M.J. McNamee \& S.J. Parry, pp. 35-53. London: Routledge.

Strelan, P. \& Boeckmann, R.J. (2003) A new model for understanding performance enhancing drug use by elite athletes. Journal of Applied Sport Psychology, 15 (2), pp. 176-183. 
Strelan, P. \& Boeckmann, R.J. (2006) Why drug testing in elite sport does not work: Perceptual deterrence theory and the role of personal moral beliefs. Journal of Applied Social Psychology, 36 (12), pp. 2909-2934.

Volkwein, K.A. (1995) Ethics and top-level sport - a paradox? International Review for the Sociology of Sport, 30 (3-4), pp. 311-321.

WADA (2009) World Anti-Doping Code. Downloaded 30 September 2009 from http://www.wada-ama.org/en/World-Anti-Doping-Program/Sports-andAnti-Doping-Organizations/The-Code/

Weber, J. \& Glyptis, S.M. (2000) Measuring the impact of a business ethics course and community service experience on students' values and opinions. Teaching Business Ethics, 4 (4), pp. 341-358.

Wright, M. (1995) Can moral judgement and ethical behaviour be learned? A review of the literature. Management Decision, 33 (10), pp. 17-28. 